\title{
Mff Media

\section{REVIEW ARTIKEL: PENGGUNAAN LIPID ASAM STEARAT DALAM SISTEM PENGHANTARAN OBAT BERBASIS NANOPARTIKEL}

\section{Review Article: The Use Of Stearic Acid Lipids In Nanoparticle-Based Drug Delivery Systems}

Vica Aspadiah, Sitti Nuraisyah Wahyuningrum, Adryan Fristiohady ${ }^{*}$

Jurusan Farmasi, Fakultas Farmasi, Universitas Halu Oleo, Kota Kendari

*Koresponden E-mail: adryanfristiohady@uho.ac.id

DOI: https://doi.org/10.32382/mf.v16i2.1622

\begin{abstract}
The pharmaceutical formulation continues to be developed in order to obtain maximum therapeutic effects with minimal side effects. The increasing use of nanoparticles in pharmaceutical products is based on the fact that the preparations manufactured with the nanoparticle system have an advantage such as active substances, which are selective and effectively meet up with the targeted site and the active substances, which are released in order to control and minimize any adverse side effects. Furthermore, literature searches were carried out using online-based library search tools, such as Google Scholar, NCBI-PubMed and ELSEVIER for a total of 50 articles. The use of stearic acid as a nanoparticles matrix are used as a carrier for lipophilic active substances and are able to control the active substances release. This research provides information on the use of stearic acid lipids in various nanoparticle preparations.
\end{abstract}

Key words: Stearic acid, Lipids, Nanoparticles

\begin{abstract}
ABSTRAK
Pengembangan formulasi sediaan farmasi terus mengalami pengembangan untuk mendapatkan efek terapi yang maksimal dengan efek samping seminimal mungkin. Peningkatan penggunaan nanopartikel dalam produk farmasi karena sediaan yang dibuat menggunakan sistem nanopartikel memiliki keuntungan yaitu zat aktif dapat mencapai tempat aksi yang ditargetkan secara selektif dan efektif serta pelepasan zat aktif dapat dikontrol untuk meminimalisir adanya efek samping yang merugikan. Penelusuran pustaka dilakukan menggunakan instrumen pencarian pustaka berbasis online, seperti Google Scholar, NCBI-PubMed dan ELSEVIER sebanyak 50 artikel. Penggunaan asam stearat sebagai matriks nanopartikel dapat digunakan sebagai pembawa untuk zat aktif yang bersifat lipofilik dan dapat mengontrol pelepasan zat aktif. Review ini memberikan informasi mengenai penggunaan lipid asam stearat pada berbagai macam sediaan nanopartikel.
\end{abstract}

Kata kunci : Asam stearat, Lipid, Nanopartikel

\section{PENDAHULUAN}

Formulasi dalam bidang farmasi terus mengalami perkembangan, salah satunya dengan terciptanya nanoteknologi. Nanoteknologi banyak digunakan dalam kehidupan sehari-hari, contohnya partikel nanoscopic dengan sifat pelepasan zat aktif obat yang ditingkatkan. Nanoteknologi sampai saat ini masih terus dikembangkan (Griffin et al., 2018). Tujuan dari nanoteknologi secara umum yaitu mendiagnosis seakurat dan sedini mungkin serta mengobati seefektif mungkin tanpa efek samping dengan penghantaran obat yang terkontrol dan disesuaikan (Yadaf et al., 2013).

Nanoteknologi memiliki beberapa keuntungan yaitu memodifikasi atau pengontrolan pelepasan senyawa aktif sehingga meminimalisir efek samping dari senyawa aktif tersebut dan dapat diberikan dalam konsentrasi tinggi karena permukaan partikel yang luas dan ukuran partikel yang kecil sehingga obat dapat mencapai tempat aksi yang ditargetkan secara selektif dan efektif, pelepasan senyawa aktif yang berukuran kecil dan kapasitas pemuatan untuk mengantarkan obat yang tinggi. Persyaratan nanopartikel yang ideal yaitu partikel tersebut harus dapat masuk kedalam aliran darah dan masuk ke dalam sel dan jaringan target (Hanutami \& Budiman, 2017).

Zat aktif atau molekul obat melekat dan diadsorbsi secara kimia oleh matriks nano atau dienkapsulasi di dalam matriks nanopartikel. 
Proses enkapsulasi obat dalam biomaterial, seperti polimer dan lipid, memiliki keuntungan yaitu memungkinkan terapi multidrug, seperti obat yang bersifat hidrofobik dan obat yang bersifat hidrofilik, dan pelepasan obat yang dapat dikontrol. Pengetahuan mengenai komposisi nanopartikel, meliputi satu atau lebih bahan obat dan matriks sangat penting dalam pengembangan formulasi untuk menghasilkan formula yang optimal (Sapra et al., 2017).

Penargetan obat mencapai ke jaringan target akan meningkatkan efisiensi efek terapeutik yang dihasilkan oleh zat aktif atau obat, juga dapat mengurangi dosis atau jumlah obat yang harus diberikan atau dikonsumsi sehingga dapat mengurangi efek toksik atau efek samping obat yang tidak diinginkan. Pengembangan sistem penghantaran obat dengan berbasis lipid, misalnya liposom, misel, nanokapsul, dan Solid Lipid Nanoparticles (SLN), bertujuan agar dapat melarutkan obat yang larut pada lemak atau lipofilik. Sistem penghantaran obat berbasis lipid memiliki keunggulan yaitu disusun oleh lipid yang diturunkan secara biokompatibel atau aman untuk tubuh manusia sehingga memiliki efek toksisitas yang lebih rendah (Raut et al., 2018). Dibandingkan dengan penggunaan polimer yang memiliki efek samping karena terbuat dari monomer dan pelarut organik yang memiliki efek toksisitas tinggi, serta tidak bersifat biodegradable (Rahmi, 2010).

Nanocarrier berbasis lipid biasanya terbentuk dari lipid fisiologis karena dapat ditoleransi dengan baik oleh tubuh manusia, biasanya tidak beracun dan hasil dekomposisinya menjadi residu yang tidak beracun. Sediaan yang menggunakan nanocarrier berbasis lipid yaitu liposom, niosom, etosom, transferosom, Solid Lipid Nanoparticles (SLN), Nanostructured Lipid Carriers (NLC) dan nanoemulsi. SLN disusun oleh campuran lipid padat yang tersebar pada bagian inti atau dapat disebut sebagai matriks lipid padat. NLC dibentuk oleh campuran lipid padat dan lipid cair dalam inti, sehingga matriks yang terbentuk merupakan campuran dari lipid padat dan minyak tetapi tetap padat pada suhu tubuh (Chuang et al.,2018).

Solid lipid atau lipid padat yang sering digunakan dalam formulasi nanopartikel terutama dalam formulasi Solid Lipid Nanoparticles (SLN) adalah Glyceryl behenate, Tripalmitin dan Asam stearat (Öztürk et al., 2019). Asam stearat merupakan asam lemak jenuh yang memiliki 18 atom karbon. Titik leleh asam stearat jauh lebih tinggi daripada suhu tubuh manusia, yaitu $69,6^{\circ} \mathrm{C}$. Titik leleh yang lebih tinggi daripada suhu tubuh manusia menyebabkan asam stearat dapat digunakan sebagai matriks lipid pada formulasi nanopartikel (Kumar \& Randhawa, 2015).

Menurut penelitian, penggunaan lipid asam stearat dalam sediaan nanopartikel dapat memperlambat pelepasan zat aktif karena adanya kemungkinan interaksi antara molekul zat aktif dengan lipid. Selain itu, juga termasuk radikal lipid yang dapat berperan dalam pengubahan radikal bebas menjadi lebih stabil dalam pembuatan sediaan antioksidan (Shylaja \&Mathew, 2016). Konsentrasi yang digunakan sebagai matriks dalam sediaan SLN adalah $20 \%$ (b/v) untuk menghasilkan sediaan yang berbentuk semipadat ( $\mathrm{Gad}$ et al., 2019). Oleh karena itu, pembuatan review artikel ini bertujuan untuk memberikan informasi dan edukasi mengenai penggunaan lipid asam stearat dalam formulasi nanopartikel.

\section{METODE}

Data yang digunakan dalam penulisan review artikel ini dikumpulkan menggunakan metode studi pustaka. Penelusuran pustaka dilakukan menggunakan instrumen pencarian pustaka berbasis online, seperti Google Scholar, NCBI-PubMed dan ELSEVIER. Kata kunci yang digunakan dalam penelusuran pustaka terkait dengan "aplikasi lipid asam stearat dalam nanopartikel”, "application of stearic acid lipids in nanoparticles", "nanoteknologi", "lipid asam stearat",dan "lipid stearic acid nanoparticles" Pustaka yang diperoleh kemudian disusun sesuai kerangka, penggunaan lipid asam stearat dalam nanopartikel, dan penulisan review artikel sesuai format yang diberikan. Berdasarkan hasil studi literatur diperoleh 50 artikel yang memuat informasi mengenai penggunaan lipid asam stearat dalam nanopartikel.

\section{PEMBAHASAN}

Nanoteknologi adalah ilmu yang mempelajari tentang nanopartikel, baik sintesisnya maupun pengembangannya. Nanopartikel dapat didefinisikan sebagai partikel yang berukuran $1 \mathrm{~nm}$ sampai $100 \mathrm{~nm}$. Nanopartikel digunakan untuk beragam tujuan, diantaranya dalam bidang pengembangan formulasi obat-obatan dan kosmetik (Hasan, 2015). Ukuran nanopartikel yang kecil dapat meningkatkan kelarutan zat aktif atau obat karena luas permukaannya meningkat sehingga mengalami perluasan. Hal ini menyebabkan pendistribusian zat aktif ke tempat target melalui alitran darah lebih mudah dan kemampuan penyerapan ke tempat target semakin besar (Suprapto, 2019).

Lipid Nanoparticle Formulations 
(LNF) sebagai sistem nanocarrier yang memberikan banyak manfaat terkait enkapsulasi obat-obatan, memberikan stabilitas kinetik dan morfologi struktural yang kaku dibandingkan dengan vesikuler berbasis lipid lainnya, misalnya liposom dan liposom kationik, maupun emulsi (Emulsi lipid) dalam sistem nanocarrier koloid. LNF menunjukkan sitotoksisitas rendah dan memiliki stabilitas produksi yang baik. Pengembangan berbagai macam LNF yaitu Solid Lipid Nanoparticles (SLN), Nanostructured Lipid Carriers (NLC), Lipid-Drug Conjugates (LDC), dan lain-lain (Banerjee \& Kundu, 2018).

\section{Solid Lipid Nanoparticles (SLN)}

Definisi SLN

SLN adalah sistem pembawa menggunakan lipid padat untuk meningkatkan bioavailabilitas obat yang memiliki kelarutan rendah (Amalia et al., 2015). SLN sangat baik sebagai pembawa partikel koloid, seperti emulsi, liposom, polimer mikro dan nanopartikel (Yadaf et al., 2013).

\section{Struktur dan Morfologi SLN}

Gambar ilustrasi mengenai struktur SLN dapat dilihat pada gambar 1. SLN diilustrasikan sebagai bola yang mengandung beberapa komponen penysun.

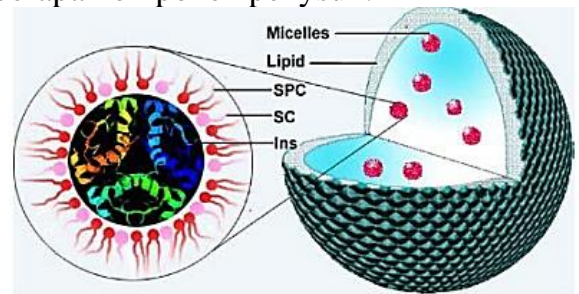

Gambar 1. Struktur Solid Lipid Nanoparticles (SLN) (Yadav et al., 2013)

SLN terdiri dari 3 bahan utama yaitu zat aktif atau obat, lipid padat, seperti asam stearat dan surfaktan. Surfaktan bertindak sebagai penghalang antara matriks lipid dan bagian luarnya. Lipid padat, misalnya asam stearat, bertindak sebagai matriks lipid dan zat aktif atau obat berada dalam matriks lipid tersebut (Yadav et al., 2013).

Gambar morfologi SLN dapat dilihat pada gambar 2. Gambar ini merupakan contoh dari morfologi SLN dengan zat aktif Q10 yang diamati menggunakan TEM.

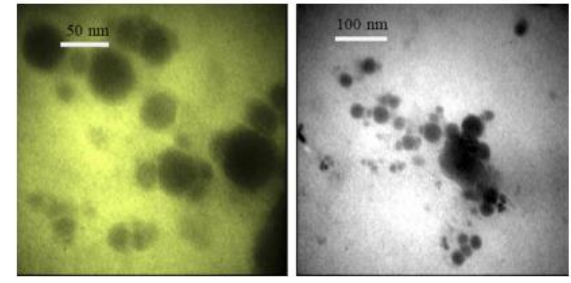

Gambar 2. Morfologi Solid Lipid Nanoparticles (SLN) Q10 (Farboud et al., 2011)

Pengamatan menggunakan Transmission Electron Microscopy (TEM) dapat dikonfirmasi bahwa ukuran partikel SLN Q10 dalam rentang antara $50 \mathrm{~nm}-100 \mathrm{~nm}$ (Farboud et al., 2011).

\section{Keuntungan SLN}

Keuntungan dari SLN yaitu dapat mengontrol pelepasan obat, dapat meningkatkan stabilitas obat, dapat mengkombinasi obat hidrofilik dan lipofilik, menghindari pembawa obat yang bersifat toksik dan juga menghindari penggunaan pelarut organik, dapat memberikan efek oklusif, loading obat yang tinggi, interaksi fase di antarmuka dan dapat meningkatkan kinerja farmasetik (Rahmi, 2010; Jafar et al., $\underline{2015)}$.

\section{Kerugian SLN}

Kerugian SLN adalah jumlah muatan obat yang terbatas, adanya kerusakan obat atau kebocoran selama penyimpanan apabila dibandingkan dengan NLC, rendahnya daya muat untuk beberapa obat, dan kandungan air yang tinggi untuk melarutkan SLN (Annisa et al., 2016; Angelia et al., 2019).

\section{Komponen SLN}

SLN terdiri dari lipid padat (lipid padat pada suhu kamar dan pada suhu tubuh manusia), misalnya asam stearat, distabilkan oleh surfaktan (pengemulsi), misalnya tween 80, kosurfaktan (air atau pelarut) dan zat aktif dalam gradien (biasanya obat) (Basha et al., 2020).

\section{Mekanisme pelepasan SLN}

SLN yang diinkorporasikan dalam sediaan topikal mampu membentuk lapisan oklusif pada permukaan kulit yang dipengaruhi oleh ukuran SLN yaitu kurang dari $400 \mathrm{~nm}$. Ketika SLN diaplikasikan pada permukaan kulit, air yang terkandung dalam sediaan akan menguap dan meninggalkan lapisan adesif yang menutupi kulit, sehingga dapat menurunkan transepideral water loss yang dapat menyebabkan obat berpenetrasi ke lapisan kulit terdalam, mengurangi kerapatan korneosit dan memperluas gap interkorneosit (Mappamasing et 
al., 2015).

\section{Nanostructured Lipid Carriers (NLC) Definisi NLC}

NLC merupakan pengembangan dari Solid Lipid Nanoparticles (SLN). Modifikasi ini dilakukan untuk meningkatan pemuatan obat pada matriks lipid dan mencegah kebocoran pada matriks lipid sehingga dapat meningkatkan keefektifan dalam meningkatkan pemuatan obat dan dapat memodulasi pelepasan obat. Perkembangan atau modifikasi ini dilakukan dengan pencampuran lipid padat atau solid lipid dengan lipid cair atau minyak (Severino et al. 2012).

\section{Morfologi NLC}

Gambar morfologi NLC dapat dilihat pada gambar 3. Gambar ini merupakan contoh dari morfologi NLC dengan zat aktif Retinil palmitat yang diamati menggunakan TEM.
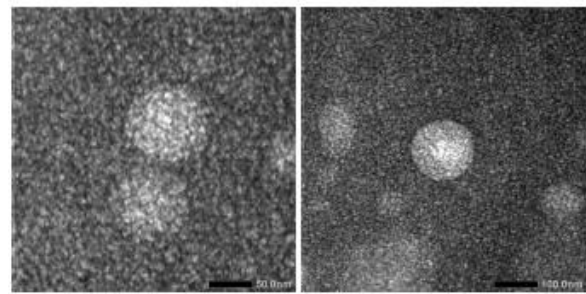

Gambar 3. Morfologi Nanostructured Lipid Carriers (NLC) Retinil palmitat (Sriarumtias et al., 2017)

Pengamatan morfologi NLC dilakukan menggunakan Transmission Electron Microscopy (TEM). Sebelah kiri menggunakan marker $50 \mathrm{~nm}$ dengan perbesaran 80000 kali dan sebelah kanan menggunakan marker $100 \mathrm{~nm}$ dengan perbesaran 40000 kali. Morfologi NLC Retinil palmitat yang diamati berbentuk sferis (Sriarumtias et al., 2017).

\section{Keuntungan NLC}

Keuntungan NLC adalah dapat memuat jumlah molekul obat yang lebih banyak daripada SLN, dapat meminimalkan kerusakan senyawa aktif dalam masa penyimpanan, dan dapat mencegah penggabungan partikel (Annisa et al. 2016; Aisiyah et al., 2019).

\section{Kerugian NLC}

Kerugian NLC adalah terdapat beberapa senyawa yang tidak tepat diformulasikan dalam sediaan NLC, misalnya senyawa antioksidan (Aisiyah et al., 2019).

\section{Komponen NLC}

Umumnya, komponen dalam formulasi NLC yaitu lipid padat, lipid cair, surfaktan dan kosurfaktan. Lipid padat yang biasa digunakan, misalnya gliseril monostearat, gliseril behenat, setil alkohol dan asam stearat.Lipid cair yang biasa digunakan, misalnya isopropil miristat, dan asam oleat. Surfaktan yang biasa digunakan misalnya tego care 450 , polisorbat 80 dan poloxamer 188. Kosurfaktan yang biasa digunakan yaitu etanol, propilen glikol, gliserin, dan sukrosa stearat (Sriarumtias et al., 2017). NLC diformulasikan dengan membentuk matriks lipid padat pada suhu kamar dan pada suhu tubuh. Matriks lipid dalam NLC terdiri dari campuran lipid padat dan minyak. Perbandingan antara lipid padat dan minyak yang paling stabil yaitu antara 70:30 hingga 99,9:0,1 (Weberet al. 2014).

\section{Mekanisme pelepasan NLC}

NLC yang diinkorporasikan dalam sediaan krim diaplikasikan ke permukaan kulit kemudian terjadi proses difusi melalui statum korneum yang difasilitasi oleh matriks NLC yang banyak mengandung lipid karena adanya kesamaan sifat polaritasnya (Sriarumtias et al. 2017). Faktor yang mempengaruhi pelepasan obat adalah viskositas dan ikatan kimia bahan aktif dengan pembawanya. Semakin besar penjerapan molekul obat, maka gradien konsentrasi dalam sistem akan meningkat, sehingga dorongan untuk terlepas akan semakin besar. Cara untuk meningkatkan daya absorbsi menembus kulit dan bercampur dengan sistem barrier, dalam hal ini stratum korneum, adalah dengan penambahan bahan enhancher, misalnya Tween-80 (Annisa et al., 2016).

\section{Perbandingan $S L N$ dan $N L C$}

Dalam pembuatan matriks lipid dalam NLC, struktur kristalnya banyak mengarah ke ketidaksempurnaan kristal sehingga menyebabkan banyak ruang untuk penempatan molekul obat maupun molekul zat aktif. Sedangkan pada SLN, struktur kristalnya lebih teratur, sehingga lebih sedikit kandungan molekul obat dalam matriks lipid (Weber et al., 2014).

\section{Lipid-Drug Conjugate (LDC) Definisi LDC}

LDC adalah molekul obat yang telah dimodifikasi secara kovalen dengan lipid. Berdasarkan struktur kimia obat dan lipid, dapat menjadi strategi dalam mengkonjugasi dan menghubungkan struktur kimia dalam mengembangkan formulasi untuk mensintesis LDC. Sehingga, dengan adanya pengembangan strategi formulasi LDC, dapat meningkatkan penghantaran obat menuju tempat aksi yang 
ditargetkan. Lipid yang berbeda digunakan untuk mensintesis konjugat (Irby et al., 2017).

Morfologi $L D C$

Gambar morfologi LDC dapat dilihat pada gambar 4. Gambar ini merupakan contoh morfologi LDC dengan zat aktif Isoniazid yang diamati menggunakan TEM.

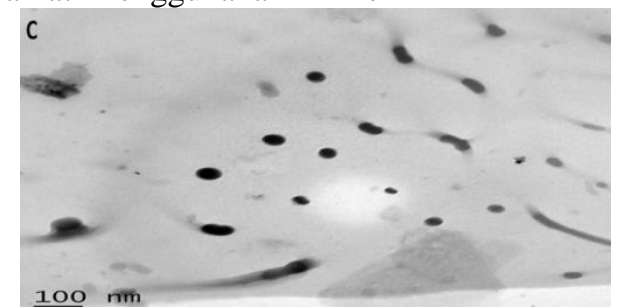

Gambar 4. Morfologi LDC Isoniazid (Pandit et al. 2020)

\section{Pengamatan morfologi LDC dilakukan menggunakan Transmission Electron} Microscopy (TEM). Berdasarkan pengamatan tersebut, diperoleh hasil LDC Isoniazid tersebut memiliki partikel-partikel yang terpisah atau tidak adanya gumpalan, berbentuk bulat, halus dan berukuran seragam, mulai dari $100 \mathrm{~nm}$ hingga $200 \mathrm{~nm}$ (Pandit et al., 2020).

\section{Keuntungan LDC}

Keuntungan LDC yaitu lipid yang digunakan bersifat biokompatibel dengan toksisitas rendah, berbentuk padat pada suhu tubuh dan kamar, memiliki kapasitas tinggi untuk mengikat obat hidrofilik karena adanya konjugasi membentuk ikatan kovalen (baik dengan pembentukan eter atau ester) atau dengan pembentukan garam dengan asam lemak, obat hidrofilik yang sangat kuat dengan indeks terapi rendah dapat terkonjugasi dengan mudah, LDC memiliki efisiensi konjugasi tinggi, dapat dengan mudah melewati saluran gastrointestinal, memungkinkan dalam menghindari degradasi oleh enzimatik atau $\mathrm{pH}$, meningkatkan penyerapan bioaktif oral melalui peningkatan serapan limfatik, control atau target pelepasan obat dan kinetika senyawa konjugasinya, dapat meningkatkan stabilitas dan bioavalilabilitas dari zat aktif yang digunakan, formulasi LDC layak mencapai tingkat industri massal (Banerjee\& Kundu, 2018).

\section{Komponen LDC}

Komponen pembentuk LDC yaitu matriks lipid terdiri dari berbagai asam lemak, misalnya asam stearat, asam oleat, asam palmitat, asam miristat, asam laurat, asam kaprilat, squalene dan lain-lain, asilgliserol atau gliserida (gliseril monostearat, gliseril distearat, gliseril tristearat, glyceryl behenate, glyceryl palmitostearate dan lain-lain), lilin (lilin lebah dan cetyl palmitate), berbagai lipid yang diturunkan dari membran biologis (fosfolipid dan sphingomielin). Surfaktan, termasuk lipid dari membran biologis, juga dapat digunakan dalam preparasi LDC. Surfaktan yang digunakan berupa lesitin, garam empedu (sodium taurocholate, natrium glikolat), sterol (kolesterol), asam lemak etoksilat, surfaktan non-ion biokompatibel (Span 80, Tween 80, poloxamer-188 dan lain-lain.) dan campurannya yang dapat bertindak sebagai stabilizer (Banerjee dan Kundu, 2018).

\section{Mekanisme pelepasan LDC}

Pelepasan molekul obat dari LDC yang berkepanjangan mungkin dimediasi oleh disintegrasi awal molekul LDC pada permukaan LDC diikuti oleh pemutusan ikatan amida selama LDC melewati asam, misalnya dalam simulasi yaitu simulasi $\mathrm{pH}$ usus, dan berkonjugasi (Pandit et al., 2020).

Gambar skema pembentukan bulk LDC dengan ikatan amida dalam pelepasan obat dari sistem LDC dapat dilihat pada gambar 5.

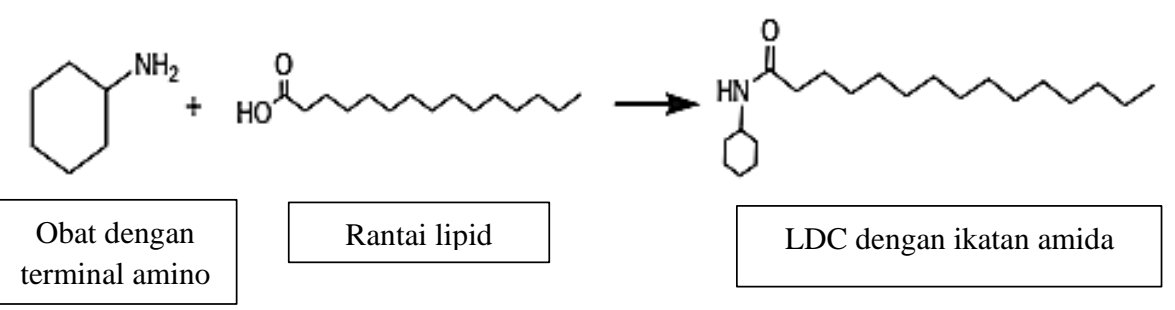

Gambar 5. Skema pembentukan bulk LDC melalui ikatan amida (Banerjee \& Kundu, 2018)

Obat yang bersifat hidrofilik dikonversi menjadi obat lipofilik dengan konjugasi gugus amino yang bebas, jika ada, dengan asam karboksilat bebas dari asam lemak untuk membentuk ikatan amida. Dalam pereaksiannya, dapat ditambahkan dengan katalis bermuatan positif untuk mempercepat reaksi (Banerjee \& Kundu, 2018).

\section{Metode Pembuatan SLN, NLC dan LDC}

Pertama, homogenisasi bertekanan tinggi. Untuk SLN, obat didispersikan dalam 
lelehan lipid padat, biasanya sekitar $5-10^{\circ} \mathrm{C}$ di atas titik lebur lipid padat tersebut. Untuk NLC, obat dilarutkan dalam campuran lipid padat yang telah dilelehkan dan lipid cair (minyak) dengan suhu sedikit di atas titik leleh campuran lipid. Untuk LDC diproduksi pada suhu kamar. Kemudian, lipid yang mengandung obat atau bulk LDC didispersikan dalam surfaktan atau larutan stabilizer pada suhu yang identik dengan kecepatan pengadukan yang tinggi hingga menghasilkan praemulsi minyak-air dalam air (untuk SLN dan NLC) atau suspensi (untuk LDC). Untuk mencapai dipersi yang tinggi dalam proses homogenisasi berikutnya, disarankan menggunakan surfaktan dengan molekul yang rendah sehingga menghasilkan dispersi yang efisien, cepat menyebar, stabil secara elektrostatik. Penambahan surfaktan dapat mencegah fenomena koalesensi. Kemudian, preemulsi atau suspensi melalui homogenizer tekanan tinggi dengan suhu yang dikontrol. Untuk SLN dan NLC biasanya sekitar $5^{\circ} \mathrm{C}$ di atas titik leleh fase lipid dan suhu kamar untuk LDC. Pada prinsipnya untuk produksi SLN dan NLC, satu siklus homogenisasi pada 500 bar cukup untuk menghasilkan emulsi panas minyak dalam air dengan ukuran partikel kira-kira 250-300 nm.
Pendinginan nanoemulsi selama produksinya mengarah pada kristalisasi lipid dan pembentukan nanopartikel padat (Muchow et al., $\underline{2008)}$.

\section{Karakterisasi SLN, NLC dan LDC}

Karakterisasi pada Solid Lipid Nanoparticles (SLN), Nanostructured Lipid Carrier (NLC) dan Lipid-Drug Conjugate (LDC) memiliki kesamaan yaitu analisis ukuran partikel, analisis indeks polidispersitas, analisis zeta potensial, analisis bentuk morfologi nanopartikel dan analisis in-vitro. Perbedaan pada karakterisasi SLN, NLC dan LDC adalah pada SLN dan NLC terdapat analisis efisiensi penjerapan obat dan pada LDC terdapat karakterisasi bulk LDC (Mappamasing dkk., 2015; Sriarumtias et al., 2017; Pandit et al., $\underline{2020}$ ).

Aplikasi asam stearat banyak digunakan dalam formulasi sediaan farmasi. Asam stearat merupakan lipid GRAS yang diketahui sangat aman dan banyak digunakan dalam makanan, obat-obatan, dan kosmetik (Mahajan \& Kaur, 2018). Penggunaan asam stearat dalam formulasi nanopartikel dapat dilihat pada tabel 1 .

Tabel 1. Penggunaan Asam Stearat dalam Nanopartikel

\begin{tabular}{|c|c|c|c|c|}
\hline NO & SEDIAAN & KEGUNAAN & Key Findings & SUMBER \\
\hline 1. & $\begin{array}{l}\text { Solid Lipid } \\
\text { Nanoparticles } \\
(\mathrm{SLN})\end{array}$ & $\begin{array}{l}\text { Sebagai bahan pembentuk } \\
\text { matriks dalam pembuatan } \\
\text { SLN dengan zat aktif } \\
\text { Glikazid. }\end{array}$ & $\begin{array}{l}\text { Pembuatan SLN menggunakan } \\
\text { lipid asam stearat dengan zat } \\
\text { aktif Glikazid memiliki ukuran } \\
\text { partikel } 878,0 \pm 243,3 \mathrm{~nm} \text { dan } \\
745,8 \pm 204,0 \mathrm{~nm} \text {; nilai zeta } \\
\text { potensial }-396 \pm 0,45 \mathrm{mV} \text { dan - } \\
5,32 \pm 2,13 \mathrm{mV} \text {; dan efisiensi } \\
\text { penjerapan } 84,055 \pm 3,876 \% \\
\text { dan } 75,29 \pm 0,79 \% \text {. }\end{array}$ & $\begin{array}{l}\text { Amalia et al., } \\
\underline{2015} .\end{array}$ \\
\hline 2. & $\begin{array}{l}\text { Krim } \\
\text { nanopartikel }\end{array}$ & $\begin{array}{l}\text { Sebagai fase lipid dalam } \\
\text { pembuatan } \\
\text { nanopartikel kitosan. }\end{array}$ & $\begin{array}{l}\text { Krim nanopartikel dengan zat } \\
\text { aktif kitosan menggunakan fase } \\
\text { lipid asam stearat yang } \\
\text { dikombinasikan dengan } \\
\text { emulgator span dan tween } \\
\text { menghasilkan krim yang stabil } \\
\text { secara fisik dan memiliki zona } \\
\text { hambat 13,46 mm terhadap } \\
\text { Propionibacterium acnes. }\end{array}$ & $\underline{\text { Riski \&Sami, }}$ \\
\hline 3. & $\begin{array}{l}\text { Solid Lipid } \\
\text { Nanoparticles } \\
(\mathrm{SLN})\end{array}$ & $\begin{array}{l}\text { Sebagai fase lipid dalam } \\
\text { pembuatan SLN dengan } \\
\text { zat aktif Alfa tokoferol. }\end{array}$ & $\begin{array}{l}\text { Pembuatan SLN menggunakan } \\
\text { lipid asam stearat dengan zat } \\
\text { aktif Alfa tokoferol } \\
\text { menghasilkan stabilitas fisik, } \\
\text { kandungan obat dan efisiensi } \\
\text { penjeratan yang baik. }\end{array}$ & $\begin{array}{l}\text { Shylaja } \\
\text { Mathew, } \\
\underline{2016} .\end{array}$ \\
\hline 4. & $\begin{array}{l}\text { Krim } \\
\text { nanopartikel }\end{array}$ & $\begin{array}{l}\text { Fase lipid } \\
\text { pembuatan } \\
\text { nanopartikel. }\end{array}$ & $\begin{array}{l}\text { Pembuatan krim nanopartikel } \\
\text { dengan fase lipid asam stearat }\end{array}$ & $\begin{array}{l}\text { Suprobo \& } \\
\text { Rahmi, 2015. }\end{array}$ \\
\hline
\end{tabular}




\begin{tabular}{|c|c|c|c|c|}
\hline & & & $\begin{array}{l}\text { mengahsilkan bentuk yang } \\
\text { padat, putih dan bau khas. }\end{array}$ & \\
\hline 5. & $\begin{array}{l}\text { Solid Lipid } \\
\text { Nanoparticles } \\
(\mathrm{SLN})\end{array}$ & $\begin{array}{l}\text { Sebagai peningkat } \\
\text { stabilitas senyawa dengan } \\
\text { teknik enkapsulasi pada } \\
\text { sediaan antikanker } \\
\text { (Variabilin) dari spons laut } \\
\text { Ircinia sp dalam bentuk } \\
\text { SLN. }\end{array}$ & $\begin{array}{l}\text { Pembuatan SLN menggunakan } \\
\text { lipid asam stearat dengan zat } \\
\text { aktif Variabilin dari spons laut } \\
\text { Ircinia sp dapat meningkatkan } \\
\text { stabilitas senyawa. }\end{array}$ & $\frac{\text { Lerata et al., }}{\underline{2020 .} .}$ \\
\hline 6. & $\begin{array}{l}\text { Solid Lipid } \\
\text { Nanoparticles } \\
(\mathrm{SLN})\end{array}$ & $\begin{array}{l}\text { Sebagai matriks dalam } \\
\text { pembuatan SLN dengan } \\
\text { zat aktif Candesartan } \\
\text { cilexetil (CDC). }\end{array}$ & $\begin{array}{l}\text { Pembuatan SLN menggunakan } \\
\text { lipid asam stearat dengan zat } \\
\text { aktif CDC menghasilkan nilai } \\
\text { penjeratan obat yang tinggi, } \\
\text { stabilitas yang baik dan dapat } \\
\text { memberikan pelepasan obat } \\
\text { berkelanjutan, sehingga dapat } \\
\text { memberikan efek terapeutik } \\
\text { yang konstan dan } \\
\text { berkepanjangan. }\end{array}$ & $\begin{array}{l}\text { Mahajan \& } \\
\text { Kaur, 2018. }\end{array}$ \\
\hline 7. & $\begin{array}{l}\text { Solid Lipid } \\
\text { Nanoparticles } \\
(\mathrm{SLN})\end{array}$ & 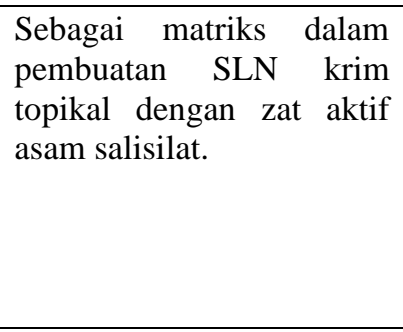 & $\begin{array}{l}\text { Pembuatan SLN menggunakan } \\
\text { lipid asam stearat dengan zat } \\
\text { aktif asam salisilat dapat } \\
\text { meningkatkan efisiensi } \\
\text { enkapsulasi sehingga dapat } \\
\text { meningkatkan efek terapeutik } \\
\text { dalam penggunaan secara } \\
\text { topikal. }\end{array}$ & $\begin{array}{ll}\text { Woo et al., } \\
\underline{2014} .\end{array}$ \\
\hline 8. & $\begin{array}{l}\text { Solid Lipid } \\
\text { Nanoparticles } \\
(\mathrm{SLN})\end{array}$ & $\begin{array}{l}\text { Sebagai matriks dalam } \\
\text { pembuatan SLN dengan } \\
\text { zat aktif Etoricoxib. }\end{array}$ & $\begin{array}{l}\text { Pembuatan SLN menggunakan } \\
\text { lipid asam stearat dengan zat } \\
\text { aktif Etoricoxib dapat } \\
\text { meningkatkan penjeratan zat } \\
\text { aktif. }\end{array}$ & $\begin{array}{l}\text { Kesharwani } \\
\text { et al., } 2016\end{array}$ \\
\hline 9. & $\begin{array}{l}\text { Solid Lipid } \\
\text { Nanoparticles } \\
(\mathrm{SLN})\end{array}$ & $\begin{array}{l}\text { Sebagai pembawa zat aktif } \\
\text { Rifampicin yang bersifat } \\
\text { lipofilik dalam bentuk } \\
\text { sediaan SLN. }\end{array}$ & $\begin{array}{l}\text { Pembuatan SLN menggunakan } \\
\text { lipid asam stearat dengan zat } \\
\text { aktif Rifampicin dapat } \\
\text { meningkatkan stabilitas dan } \\
\text { melepaskan zat aktif secara } \\
\text { berkelanjutan. }\end{array}$ & $\begin{array}{l}\text { Sivadasan et } \\
\text { al.,2013. }\end{array}$ \\
\hline 10. & $\begin{array}{l}\text { Nanostructured } \\
\text { Lipid Carriers } \\
\text { (NLC) }\end{array}$ & $\begin{array}{l}\text { Sebagai pembawa pada } \\
\text { formulasi NLC sebagai } \\
\text { sediaan topikal dengan zat } \\
\text { aktif Aceclofenac. }\end{array}$ & $\begin{array}{l}\text { Pembuatan NLC menggunakan } \\
\text { lipid asam stearat sebagai lipid } \\
\text { padat dengan zat aktif } \\
\text { Aceclofenacmenunjukkan tidak } \\
\text { adanya interaksi obat, polimer } \\
\text { dan antarformulasi dan dapat } \\
\text { meningkatkan efiensi penjeratan } \\
\text { obat. }\end{array}$ & $\frac{\text { Sethuraman }}{\text { et al., 2018. }}$ \\
\hline 11. & $\begin{array}{l}\text { Solid Lipid } \\
\text { Nanoparticles } \\
(\mathrm{SLN})\end{array}$ & $\begin{array}{l}\text { Sebagai zat penjerat zat } \\
\text { aktif lipofilik pada sediaan } \\
\text { SLN dengan zat aktif } \\
\text { Dimethyl fumarate (DMF) } \\
\text { sehingga DMF memiliki } \\
\text { kelarutan } \\
\text { biokompabilitas } \\
\text { sangat baik. }\end{array}$ & $\begin{array}{l}\text { Pembuatan SLN menggunakan } \\
\text { lipid asam stearat dengan zat } \\
\text { aktif DMF dapat meningkatkan } \\
\text { profil farmakokinetik dan } \\
\text { bioavailabilitas. }\end{array}$ & $\begin{array}{l}\text { Kumar et al., } \\
\underline{2017 .} .\end{array}$ \\
\hline 12. & $\begin{array}{l}\text { Solid Lipid } \\
\text { Nanoparticles } \\
(\mathrm{SLN})\end{array}$ & $\begin{array}{llr}\text { Sebagai } & \text { fase lipid pada } \\
\text { sediaan } & \text { SLN dengan zat } \\
\text { aktif } & \text { Cisplatin yang }\end{array}$ & $\begin{array}{l}\text { Pembuatan SLN menggunakan } \\
\text { lipid asam stearat dengan zat } \\
\text { aktif Cisplatin menghasilkan }\end{array}$ & $\begin{array}{l}\text { Raut et al., } \\
\underline{2018} .\end{array}$ \\
\hline
\end{tabular}




\begin{tabular}{|c|c|c|c|c|}
\hline & & $\begin{array}{l}\text { pembuatannya } \\
\text { menggunakan } \\
\text { nanoemulsi. }\end{array}$ & $\begin{array}{l}\text { ukuran partikel nano, distribusi } \\
\text { ukuran sempit dan partikel } \\
\text { berbentuk bola. Persen efisiensi } \\
\text { penjeratan dan persen kapasitas } \\
\text { obat berada dalam batas yang } \\
\text { dapat diterima dan dapat } \\
\text { menghantarkan obat secara } \\
\text { berkelanjutan. }\end{array}$ & \\
\hline 13. & $\begin{array}{l}\text { Solid Lipid } \\
\text { Nanoparticles } \\
(\mathrm{SLN})\end{array}$ & $\begin{array}{l}\text { Sebagai basis lipid dalam } \\
\text { formulasi } \\
\text { menggunakan } \text { teknik } \\
\text { homogenisasi panas dan } \\
\text { ultrasonikasi dengan zat } \\
\text { aktif Lopinavir dan } \\
\text { Norfloxacin. }\end{array}$ & $\begin{array}{l}\text { Pembuatan SLN menggunakan } \\
\text { lipid asam stearat dengan zat } \\
\text { aktif Lopinavir dan Norfloxacin } \\
\text { dapat memfasilitasi pengiriman } \\
\text { obat yang terkontrol ke target } \\
\text { aksi. }\end{array}$ & $\begin{array}{l}\text { Dolatabadi et } \\
\underline{\text { al., 2015. }}\end{array}$ \\
\hline 14. & $\begin{array}{l}\text { Solid Lipid } \\
\text { Nanoparticles } \\
(\mathrm{SLN})\end{array}$ & $\begin{array}{l}\text { Sebagai matriks lipid padat } \\
\text { dalam sediaan SLN dengan } \\
\text { zat aktif Iburofen untuk } \\
\text { penggunaannya sebagai } \\
\text { regimen pengobatan } \\
\text { kanker pankreas. }\end{array}$ & $\begin{array}{l}\text { Pembuatan SLN menggunakan } \\
\text { lipid asam stearat dengan zat } \\
\text { aktif Iburofenmemiliki ruang } \\
\text { lingkup translasi dari } \\
\text { pengembangan formulasi SLN } \\
\text { dengan dosis rendah untuk } \\
\text { mencegah kanker pankreas. }\end{array}$ & $\begin{array}{l}\text { Thakkar et } \\
\text { al., 2015. }\end{array}$ \\
\hline 15. & $\begin{array}{l}\text { Solid Lipid } \\
\text { Nanoparticles } \\
(\mathrm{SLN})\end{array}$ & $\begin{array}{l}\text { Sebagai lipid dalam } \\
\text { formulasi SLN dengan zat } \\
\text { aktif Dexametason. }\end{array}$ & $\begin{array}{l}\text { Pembuatan SLN menggunakan } \\
\text { lipid asam stearat dengan zat } \\
\text { aktif Dexametason dapat } \\
\text { meningkatkan kelarutan obat } \\
\text { dan meningkatkan penjeratan } \\
\text { obat dengan meningkatkan } \\
\text { viskositas sediaan. }\end{array}$ & $\underline{\text { Parvin et al. }}$ \\
\hline 16. & $\begin{array}{l}\text { Solid Lipid } \\
\text { Nanoparticles } \\
(\mathrm{SLN})\end{array}$ & $\begin{array}{l}\text { Sebagai pembawa dalam } \\
\text { sediaan SLN dengan zat } \\
\text { aktif Ciprofloxacin dalam } \\
\text { bentuk lipid padat. }\end{array}$ & $\begin{array}{l}\text { Pembuatan SLN menggunakan } \\
\text { lipid asam stearat dengan zat } \\
\text { aktif Ciprofloxacin } \\
\text { menghasilkan ukuran partikel } \\
\text { dan polidispersitas rendah, } \\
\text { efisiensi pemuatan obat tinggi } \\
\text { dan pelepasan obat yang } \\
\text { terkontrol. }\end{array}$ & $\underline{\underline{\text { Alarifi et al., }}}$ \\
\hline 17. & $\begin{array}{l}\text { Nanostructured } \\
\text { Lipid Carriers } \\
\text { (NLC) }\end{array}$ & $\begin{array}{l}\text { Sebagai kerangka dasar } \\
\text { pembentuk NLC untuk } \\
\text { penstabil sediaan. Zat aktif } \\
\text { yang digunakan yaitu } \\
\text { Resveratrol. }\end{array}$ & $\begin{array}{l}\text { Pembuatan NLC menggunakan } \\
\text { lipid asam stearat sebagai lipid } \\
\text { padat dengan zat aktif } \\
\text { Resveratrolmenghasilkan } \\
\text { stabilitas penyimpanan yang } \\
\text { baik. }\end{array}$ & $\begin{array}{ll}\text { Aisiyah } & \text { et } \\
\text { al., 2019. } & \end{array}$ \\
\hline 18. & $\begin{array}{l}\text { Solid Lipid } \\
\text { Nanoparticles } \\
(\mathrm{SLN})\end{array}$ & $\begin{array}{l}\text { Sebagai lipid matriks } \\
\text { utama dalam formulasi } \\
\text { SLN dengan zat aktif } \\
\text { Klaritromisin. }\end{array}$ & $\begin{array}{l}\text { Pembuatan SLN menggunakan } \\
\text { lipid asam stearat dengan zat } \\
\text { aktif } \\
\text { Klaritromisinmenghasilkan } \\
\text { ukuran partikel, indeks } \\
\text { polidispersitas yang lebih } \\
\text { rendah dan dinyatakan layak } \\
\text { sebagai sediaan oral. }\end{array}$ & $\underline{\text { Öztürk et al., }}$ \\
\hline 19. & $\begin{array}{l}\text { Spray-drying } \\
\text { Nanoparticles }\end{array}$ & $\begin{array}{l}\text { Sebagai matriks lipid } \\
\text { metode renkapsulasi } \\
\text { dengan zat aktif Isoniazid } \\
\text { yang reparasinya } \\
\text { menggunakan reaktor } \\
\text { aerosol. }\end{array}$ & $\begin{array}{l}\text { Pembuatan Spray-drying } \\
\text { Nanoparticlesdengan zat aktif } \\
\text { Isoniazid yang dienkapsulasi } \\
\text { oleh asam stearat dapat } \\
\text { memaksimalkan kelarutan obat } \\
\text { dengan pemuatan obat yang } \\
\text { tinggi. }\end{array}$ & $\begin{array}{l}\text { Sapra et } a l ., \\
\underline{2017 .}\end{array}$ \\
\hline
\end{tabular}




\begin{tabular}{|c|c|c|c|c|}
\hline 20. & $\begin{array}{l}\text { Solid Lipid } \\
\text { Nanoparticle } \\
(\mathrm{SLN})\end{array}$ & $\begin{array}{l}\text { - Sebagai komponen lipid } \\
\text { padat pada sediaan SLN } \\
\text { dengan zat aktif insulin } \\
\text { yang dipreparasi dengan } \\
\text { metode penguapan } \\
\text { pelarut. } \\
\text { - Sebagai komponen lipid } \\
\text { padat pada sediaan SLN } \\
\text { dengan zat aktif } \\
\text { Cyclosporin A dan } \\
\text { Paklitaksel yang } \\
\text { dipreparasi dengan } \\
\text { metode mikroemulsi. } \\
\text { - Sebagai komponen lipid } \\
\text { padat pada sediaan SLN } \\
\text { dengan zat aktif Insulin } \\
\text { dan Thymopentin yang } \\
\text { dipreparasi dengan } \\
\text { metode emulsi ganda. } \\
\text { - Sebagai komponen lipid } \\
\text { padat pada sediaan SLN } \\
\text { dengan zat aktif Silibinin } \\
\text { yang dipreparasi dengan } \\
\text { metode pengendapan. } \\
\text { - Sebagai komponen lipid } \\
\text { padat pada sediaan SLN } \\
\text { dengan zat aktif Insulin } \\
\text { yang dipreparasi dengan } \\
\text { metode Coacervation. }\end{array}$ & $\begin{array}{l}\text { Pembuatan SLN menggunakan } \\
\text { lipid asam stearat dengan zat } \\
\text { aktif insulin, Cyclosporin A, } \\
\text { Paklitaksel, Thymopentin dan } \\
\text { Silibinin dapat sebagai } \\
\text { pembawa zat aktif yang baik. }\end{array}$ & $\begin{array}{l}\text { Basha et al., } \\
\underline{2020 .} \text {. }\end{array}$ \\
\hline 21. & $\begin{array}{l}\text { Solid Lipid } \\
\text { Nanoparticles } \\
(\mathrm{SLN})\end{array}$ & $\begin{array}{l}\text { Sebagai lipid utama atau } \\
\text { lipid inti dalam formulasi } \\
\text { SLN dengan zat aktif } \\
\text { Imatinib mesylate. }\end{array}$ & $\begin{array}{l}\text { Pembuatan SLN menggunakan } \\
\text { lipid asam stearat dengan zat } \\
\text { aktif Imatinib mesylate dengan } \\
\text { Quillaja saponin sebagai } \\
\text { surfaktan cocok untuk obat yang } \\
\text { ditargetkan ke otak, pemberian } \\
\text { limfatik dan vaksin. }\end{array}$ & $\begin{array}{l}\text { Siram et al., } \\
\underline{2016 .}\end{array}$ \\
\hline 22. & $\begin{array}{l}\text { Solid Lipid } \\
\text { Nanoparticles } \\
(\mathrm{SLN})\end{array}$ & 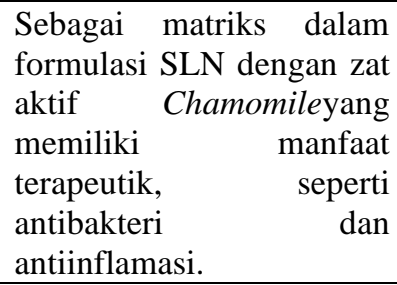 & $\begin{array}{l}\text { Pembuatan SLN menggunakan } \\
\text { lipid asam stearat dengan zat } \\
\text { aktif Chamomile dapat } \\
\text { meningkatkan } \\
\text { melewati membran sehingga } \\
\text { dapat meningkatkan efek } \\
\text { farmakologis. }\end{array}$ & $\begin{array}{l}\text { Gad et al., } \\
\underline{2019} .\end{array}$ \\
\hline 23. & $\begin{array}{l}\text { Solid Lipid } \\
\text { Nanoparticles } \\
(\mathrm{SLN})\end{array}$ & $\begin{array}{l}\text { Sebagai matriks lipid } \\
\text { dalam sediaan SLN dengan } \\
\text { zat aktif } \text { Ferrous sulfate } \\
\text { yang diformulasikan } \\
\text { dalam bentuk sediaan oral. }\end{array}$ & $\begin{array}{l}\text { Pembuatan SLN menggunakan } \\
\text { lipid asam stearat dengan zat } \\
\text { aktif } \\
\text { sulfatemenghasilkan } \quad \text { Ferrous } \\
\text { efisiensi penjeratan } 82,58 \% \text { dan } \\
\text { dinyatakan layak sebagai suatu } \\
\text { sediaan nano dengan pembawa } \\
\text { lipid. }\end{array}$ & $\begin{array}{l}\text { Hatefi\& } \\
\text { Farhadian, } \\
\underline{2020 .}\end{array}$ \\
\hline 24. & $\begin{array}{l}\text { Solid Lipid } \\
\text { Nanoparticles } \\
(\mathrm{SLN})\end{array}$ & $\begin{array}{lr}\text { Sebagai matriks } & \text { lipid } \\
\text { dengan zat } & \text { aktif } \\
\text { Enrofloxacin } & \text { yang } \\
\text { menggunakan } & \text { metode } \\
\text { pembuatan homogenisasi } \\
\text { dan ultrasonikasi. }\end{array}$ & $\begin{array}{l}\text { Pembuatan SLN menggunakan } \\
\text { lipid asam stearat dengan zat } \\
\text { aktif Enrofloxacindapat } \\
\text { meningkatkan efek } \\
\text { farmakologis, berpotensi untuk } \\
\text { menggabungkan zat aktif, dan } \\
\text { pelepasan berkelanjutan, }\end{array}$ & $\begin{array}{l}\text { Xie et al., } \\
\underline{2011 .} .\end{array}$ \\
\hline
\end{tabular}




\begin{tabular}{|c|c|c|c|c|}
\hline & & & $\begin{array}{l}\text { meningkatkan bioavailabilitas } \\
\text { dan waktu sirkulasi sistematis } \\
\text { juga meningkat. }\end{array}$ & \\
\hline 25. & $\begin{array}{l}\text { Solid Lipid } \\
\text { Nanoparticles } \\
(\mathrm{SLN})\end{array}$ & $\begin{array}{l}\text { Sebagai matriks lipid } \\
\text { biodegradable dengan zat } \\
\text { aktif Voriconazole yang } \\
\text { diberikan melalui peroral. }\end{array}$ & $\begin{array}{l}\text { Pembuatan SLN menggunakan } \\
\text { lipid asam stearat dengan zat } \\
\text { aktif Voriconazole dapat } \\
\text { meningkatkan bioavailabilitas } \\
\text { dan laju disolusi, sehingga } \\
\text { menghasilkan sediaan yang } \\
\text { efektif. }\end{array}$ & $\begin{array}{l}\text { Kelidari } \\
\underline{\text { al., } 2018 .} .\end{array}$ \\
\hline 26. & $\begin{array}{l}\text { Lipid-Drug } \\
\text { Conjugate } \\
\text { (LDC) }\end{array}$ & $\begin{array}{l}\text { Sebagai matriks pembawa } \\
\text { dalam sediaan LDC } \\
\text { dengan zat aktif Sitarabin. }\end{array}$ & $\begin{array}{l}\text { Pembuatan LDC menggunakan } \\
\text { matriks pembawa asam stearat } \\
\text { dengan zat aktif Sitarabin dapat } \\
\text { meningkatkan bioavailabilitas } \\
\text { oral dan target aksi obat yang } \\
\text { spesifik. }\end{array}$ & $\begin{array}{l}\frac{\text { Banerjee }}{\text { \&Kundu, }} \\
\underline{\underline{2018} .}\end{array}$ \\
\hline 27. & $\begin{array}{l}\text { Solid Lipid } \\
\text { Nanoparticles } \\
(\mathrm{SLN})\end{array}$ & $\begin{array}{l}\text { Sebagai matriks pembawa } \\
\text { dalam sediaan SLN dengan } \\
\text { zat aktif Paliperidon. }\end{array}$ & $\begin{array}{l}\text { Pembuatan SLN menggunakan } \\
\text { lipid asam stearat dengan zat } \\
\text { aktif Paliperidon dapat } \\
\text { mengenkapsulasi zat aktif } \\
\text { dengan baik dan dapat } \\
\text { melepaskan zat aktif secara } \\
\text { berkepanjangan. }\end{array}$ & $\begin{array}{l}\frac{\text { Kumar \& }}{\text { Randhawa, }} \\
\underline{\underline{2015} .}\end{array}$ \\
\hline 28. & $\begin{array}{l}\text { Solid Lipid } \\
\text { Nanoparticles } \\
(\mathrm{SLN})\end{array}$ & $\begin{array}{l}\text { Sebagai matriks lipid } \\
\text { dalam sediaan SLN dengan } \\
\text { zat aktif Gatifloxacin. }\end{array}$ & $\begin{array}{l}\text { Pembuatan SLN menggunakan } \\
\text { lipid asam stearat dengan zat } \\
\text { aktif Gatifloxacinmenghasilkan } \\
\text { kisaran ukuran koloid, distribusi } \\
\text { ukuran partikel yang baik, } \\
\text { efisiensi penjeratan yang tinggi, } \\
\text { stabilitas penyimpanan yang } \\
\text { baik dan dapat digunakan } \\
\text { dengan efek farmakologis yang } \\
\text { berkelanjutan. }\end{array}$ & $\begin{array}{l}\text { Kalam et al., } \\
\underline{2010 .} .\end{array}$ \\
\hline 29. & $\begin{array}{l}\text { Solid Lipid } \\
\text { Nanoparticles } \\
(\mathrm{SLN})\end{array}$ & $\begin{array}{l}\text { Sebagai fase lipid dalam } \\
\text { sediaan SLN dengan zat } \\
\text { aktif Koenzim Q-10. }\end{array}$ & $\begin{array}{l}\text { Pembuatan SLN menggunakan } \\
\text { lipid asam stearat dengan zat } \\
\text { aktif Koenzim Q-10 memiliki } \\
\text { stabilitas yang tinggi, ukuran } \\
\text { yang kecil (nano), penampilan } \\
\text { fisik yang baik dan distribusi } \\
\text { ukuran relatif sempit. }\end{array}$ & $\begin{array}{l}\text { Farboud } \\
\text { al., 2011. }\end{array}$ \\
\hline
\end{tabular}

Asam stearat banyak digunakan dalam formulasi sediaan farmasi karena memiliki biokompatibilitas yang lebih baik dan toksisitas yang lebih rendah daripada lemak yang dibuat atau yang disintesis. Asam stearat biokompatibel dengan jaringan tubuh manusia, dan netral dengan cairan fisiologis pada manusia ( $\underline{\text { Severino }}$ et al., 2011). Menurut penelitian, penggunaan lipid padat asam stearat dalam pembuatan sediaan nanopartikel menghasilkan ukuran partikel $50 \pm 10 \mathrm{~nm}$, nilai zeta potensial $-47,1 \mathrm{mV}$ dan nilai indeks polidispersitas 0,109. Sedangkan, penggunaan lipid padat setil palmitat menghasilkan ukuran partikel $100 \pm 15 \mathrm{~nm}$, nilai zeta potensial $-44,4 \mathrm{mV}$ dan nilai indeks polidispersitas 0,203 (Farboud et al., 2011).Selain itu, penggunaan lipid padat Gliseril monostearat menghasilkan ukuran partikel 334,4 $\pm 8,95 \mathrm{~nm}$, nilai zeta potensial $-27,53 \pm 0,802 \mathrm{mV}$ dan nilai indeks polidispersitas 0,289 $\pm 0,062$ (Mappamasing et al., 2015). Hal inilah yang mendasari banyaknya formulasi sediaan farmasi yang menggunakan asam stearat sebagai matriks dalam sediaan nanopartikel.

Nanopartikel lipid sangat baik digunakan untuk meningkatkan efektivitas efek terapeutik. Hal ini disebabkan karena nanopartikel lipid dapat ditoleransi dengan baik oleh fisiologis tubuh. Zat aktif yang bersifat lipofilik dan hidrofilik, termasuk senyawa labil, seperti protein dan peptida, dapat dipreparasikan dengan matriks lipid (Severino et al., 2011).

Jaringan kristal dari matriks lipid padat dalam nukleasi dibentuk dengan pengendapan 
mikroemulsi, tidak hanya meningkatkan efisiensi enkapsulasi obat, tetapi juga mengontrol pelepasan obat. Matriks lipid padat alami atau sintetis bersifat biokompatibel dan dapat terurai secara hayati, seperti asam lemak, ester gliserin, dan trigliserida. Asam stearat termasuk dalam matriks lipid padat alami (Li et al., 2016).

\section{KESIMPULAN}

Penggunaan lipid asam stearat dalam formulasi nanopartikel sebagai matriks atau pembawa berbentuk lipid padat (solid lipid) yang dapat meningkatkan disolusi partikel dan keefektifan zat aktif terutama yang bersifat lipofilik. Pengembangan terus dilakukan untuk sistem penghantaran obat dengan basis lipid asam stearat dalam sediaan nanopartikel.

\section{DAFTAR PUSTAKA}

Aisiyah, S., Harjanti, R., dan Nopiyanti, V., 2019, Pengaruh Panjang Rantai Karbon Lipid Padat terhadap Karakteristik Nanostructured Lipid Carrier Resveratrol, JPSCR: Journal of Pharmaceutical Science and Clinical Research, Vol. 4(2), doi: 10.20961/jpscr.v4i2.34408.

Alarifi, S., Massadeh, S., Al-Agamy, M., Al Aamery, M., Al Bekairy, A., dan Yassin, A.E., 2020, Enhancement of Ciprofloxacin Activity By Incorporating It In Solid Lipid Nanoparticles, Tropical Journal of Pharmaceutical Research, Vol. 19(5), ISSN: 1596-9827.

Amalia, A., Jufri, M., dan Anwar, E., 2015, Preparasi dan Karakterisasi Sediaan Solid Lipid Nanoparticle (SLN) Glikazid, Jurnal Ilmu Kefarmasian Indonesia, Vol. 13(1), ISSN: 16931831.

Angelia, F., Louisa, M., dan Menaldi, S.L., 2019, Teknologi Nano Di Bidang Dermatologi Kosmetik, Media Dermato Venereologica Indonesiana, Vol. 46(2).

Annisa, R., Hendradi, E., dan Melani, D., 2016, Pengembangan Sistem Nanostructured Lipid Carriers (NLC) Meloxicam dengan Lipid Monostearin dan Miglyol 808 Menggunakan Metode Emulsifikasi, Journal of Tropical Pharmacy and Chemistry, Vol. 3(3), ISSN: 2407-6090.

Banerjee, S., dan Kundu, A., 2018, Lipid-Drug
Conjugates: a Potential Nanocarrier System for Oral Drug Delivery Applications, DARU Journal of Pharmaceutical Sciences, Vol. 26(1), doi: 10.1007/s40199-018-0209-1.

Basha, S.K., Dhandayuthabani, R., Muzammil, M.S., dan Kumari, V.S., 2020, Solid Lipid Nanoparticles for Oral Drug Delivery, Materials Today: Proceedings, doi: https://doi.org/10.1016/j.matpr.2020. 04.109.

Chuang, S.Y., Lin, C.H., Huang, T.H., dan Fang, J.Y., 2018, Lipid-Based Nanoparticles as a Potential Delivery Approach in the Treatment of Rheumatoid Arthritis, Nanomaterials, Vol. 8(1), doi:10.3390/nano8010042.

Dolatabadi, J.E.N., Valizadeh, H., dan Hamishehkar, H., 2015, Solid Lipid Nanoparticles as Efficient Drug and Gene Delivery Systems: Recent Breakthroughs, Advanced Pharmaceutical Bulletin, Vol. 5(2), doi: 10.15171/apb.2015.022.

Farboud, E.S., Nasrollahi, S.A., dan Tabbakhi, Z., 2011, Novel Formulation and Evaluation of a Q10-loaded Solid Lipid Nanoparticle Cream: in Vitro and in Vivo Studies, International Journal of Nanomedicine, Vol. $\quad 6, \quad$ doi: 10.2147/IJN.S16815.

Gad, H.A., El-Rahman, F.A.A., dan Hamdy, G.M., 2019, Chamomile Oil Loaded Solid Lipid Nanoparticles: A Naturally Formulated Remedy to Enhance the Wound Healing, Journal of Drug Delivery Science and Technology, Vol. 50(2019), doi: https://doi.org/10.1016/j.jddst.2019.0 $\underline{1.008 .}$

Griffin, S., Masood, M.I., Nasim, M.J., Sarfraz, M., Ebokaiwe, A.P., Schäfer, K.H., Keck, C.M., dan Jacob, C., 2018, Natural Nanoparticles: A Particular Matter Inspired by Nature, Antioxidants, Vol. 7(1).

Hanutami, B., dan Budiman, A., 2017, Review Artikel: Penggunaan Teknologi Nano pada Formulasi Obat Herbal, Farmaka, Vol. 15(2).

Hasan, S., 2015, A Review On Nanoparticles: Their Synthesis and Types, Research Journal of Recent Sciences, Vol. 4, 
ISSN: 2277-2502.

Hatefi, L., dan Farhadian, N., 2020, A Safe and Efficient Method for Encapsulation of Ferrous Sulfate in Solid Lipid Nanoparticle for Non-oxidation and Sustained Iron Delivery, Colloid and Interface Science Communications, Vol. $34 \quad$ (2020), doi: https://doi.org/10.1016/j.colcom.2019 .100227.

Irby, D., Du, C., dan Li, F., 2017, Lipid-Drug Conjugate for Enhancing Drug Delivery, Molecular Pharmaceutics, Vol.14(5),doi: 10.1021/acs.molpharmaceut.6b01027

Jafar, G., Darijanto, S.T., dan Mauludin, R., 2015, Formulasi Solid Lipid Nanoparticle Ceramide, Jurnal Pharmascience, Vol. 2(2), ISSN: 24609560.

Kalam, M.A., Sultana, Y., Ali, A., Aqil, M., Mishra, A.K., dan Chuttani, K., 2010, Preparation, Characterization, and Evaluation of Gatifloxacin Loaded Solid Lipid Nanoparticles as Colloidal Ocular Drug Delivery System, Journal of Drug Targeting, Vol. 18(3), ISSN: 1029-2330.

Kelidari, H.R., Babaei, R., Nabili, M., Shokohi, T., Saeedi, M., Gholami, S., Moazeni, M., dan Nokhodchi, A., 2018, Improved Delivery of Voriconazole to Aspergillus fumigatus Through Solid Lipid Nanoparticles as an Effective Carrier, Colloids and Surfaces A: Physicochemical and Engineering Aspects, Vol. 558 (2018), doi: https://doi.org/10.1016/j.colsurfa.201 8.08.082.

Kesharwani, R., Sachan, A., Singh, S., dan Patel, D., 2016, Formulation and Evaluation of Solid Lipid Nanoparticle (SLN) Based Topical Gel of Etoricoxib, Journal of Applied Pharmaceutical Science, Vol. 6(10), ISSN: 2231-3354.

Kumar, P., Sharma, G., Kumar, R., Malik, R., Singh, B., Katare, O.P., dan Raza, K., 2017, Stearic Acid Based, Systematically Designed Oral Lipiid Nanoparticles for Enhanced Brain Delivery of Dimethyl Fumarate, Nanomedicine, Vol.12(23), doi: 10.2217/nnm-2017-0082.
Kumar, S., dan Randhawa, J.K., 2015, Solid Lipid Nanoparticles of Stearic Acid for the Drug Delivery of Paliperidone, RSC Advances, Vol. 5(84), doi: 10.1039/c5ra10642g.

Lerata, M.S., D’Souza, S., Sibuyi, N.R., Dube, A., Meyer, M., Samaai, T., Antunes, E.M., dan Beukes, D.R., 2020, Encapsulation of Variabilin in Stearic Acid Solid Lipid Nanoparticles Enhances Its Anticancer Activity in Vitro, Molecules, Vol. 25(4), doi:10.3390/molecules25040830.

Li, M., Zahi, M.R., Yuan, Q., Tian, F., dan Liang, H., 2016, Preparation and Stability Of Astaxanthin Solid Lipid Nanoparticles Based on Stearic Acid, European Journal of Lipid Science and Technology, Vol. 118(4).

Mahajan, A., dan Kaur, S., 2018, Design, Formulation, and Characterization of Stearic Acid-Based Solid Lipid Nanoparticles of Candesartan cilexetil to Augment its Oral Bioavailability, Asian Journal of Pharmaceutical adn Clinical Research, Vol. 11(4), ISSN: 2455-3891.

Mappamasing, F., Anwar, E., dan Mun'im, A., 2015, Formulasi, Karakterisasi dan Uji Penetrasi In Vitro Resveratrol Solid Lipid Nanopartikel dalam Krim Topikal. Jurnal Ilmu Kefarmasian Indonesia, Vol.13(2), ISSN: 16931831.

Muchow, M., Maincent, P., dan Müller, R.H., 2008, Lipid Nanoparticles With a Solid Matrix (SLN®, NLC®, LDC®) for Oral Drug Delivery, Drug Development and Industrial Pharmacy, Vol. 34(12), doi: 10.1080/03639040802130061.

Öztürk, A.A., Aygül, A., dan Şenel, B., 2019, Influence of Glyceryl Behenate, Tripalmitin and Stearic Acid on the Properties of Clarithromycin Incorporated Solid Lipid Nanoparticles (SLNs): Formulation, Characterization, Antibacterial Activity and Cytotoxicity, Journal of Drug Delivery Science and Technology, Vol. 54(2019), doi: https://doi.org/10.1016/j.jddst.2019.1 01240.

Pandit, S., Roy, S., Pillai, J., dan Banerjee, S., 2020, Formulation and Intracellular Trafficking of Lipid-Drug Conjugate 
Nanoparticles Containing a Hydrophilic

Antitubercular Drug for Improved Intracellular Delivery to Human Macrophages, ACS omega, Vol. 5(9), doi:

https://dx.doi.org/10.1021/acsomega. 9b03523.

Parvin, S., Rafshanjani, M.A.S., dan Kader, M.A., 2014, Formulation and Evaluation of Dexamethasone Loaded Stearic Acid Nanoparticles by Hot Homogenization Method, International Current Pharmaceutical Journal, Vol.3(12).

Rahmi, D., 2010, Lemak Padat Nanopartikel; Sintesis dan Aplikasi, Jurnal Kimia dan Kemasan, Vol. 32(1).

Rajabi, M., dan Mousa, A.S., 2016, Lipid Nanoparticles and Their Application in Nanomedicine, Current Pharmaceutical Biotechnology, Vol. 17(8), ISSN: 1873-4316.

Raut, I.D., Doijad, R.C., Mohite, S.K., dan Manjappa, A.S., 2018, Preparation and Characterization of Solid Lipid Nanoparticles Loaded with Cisplatin, Journal of Drug Delivery and Therapeutics, Vol. 8(6), ISSN: 22501177.

Riski, R., dan Sami, F.J., 2015, Formulasi Krim Anti Jerawat Dari Nanopartikel Kitosan Cangkang Udang Windu (Penaeusmonodon), Jurnal Farmasi UIN Alauddin Makassar, Vol. 3(4).

Sapra, M., Mayya, Y.S., dan Venkataraman, C., 2017, Engineering of Layered, LipidEncapsulated Drug Nanoparticles Through Spray-Drying, Colloids and Surfaces B: Biointerfaces, Vol. 154 (2017),

doi: http://dx.doi.org/10.1016/j.colsurfb.2 017.03.037.

Sethuraman, N., Shanmuganathan, S., Sandhya, K., dan Anbarasan, B., 2018, Design, Development and Characterization of Nano Structured Lipid Carrier for Topical Delivery of Aceclofenac, Indian Journal of Pharmaceutical Education and Research, Vol. 52(4).

Severino, P., Andreani, T., Macedo, A.S., Fangueiro, J.F., Santana, M.H.A., Silva, A.M., dan Souto, E.B., 2012, Current State-of-Art and New Trends On Lipid Nanoparticles (SLN and NLC) for Oral
Drug Delivery, Journal of drug delivery, Vol. 2012, doi: 10.1155/2012/750891.

Severino, P., Pinho, S.C., Souto, E.B., dan Santana, M.H., 2011, Polymorphism, Crystallinity and HydrophilicLipophilic Balance of Stearic Acid and Stearic Acid-Capric/Caprylic Triglyceride Matrices for Production of Stable Nanoparticles, Colloids and Surfaces B: Biointerfaces, Vol. 86(1), doi: 10.1016/j.colsurfb.2011.03.029.

Sharma, A., dan Baldi, A., 2018, Nanostructured Lipid Carriers: A Review, Journal of Developing Drugs, Vol. 7(2), ISSN: 2329-6631.

Shylaja, P., dan Mathew, M., 2016, Preparation and Characterization of Alpha Tocopherol Loaded Solid Lipid Nanoparticles By Hot Homogenization Method, International Journal of Pharmacy \& Pharmaceutical Research. Human Journals, Vol. 7(1), ISSN: 2349-7203.

Siram, K., Raghavan, C.V., Marslin, G., Rahman, H., Selvaraj, D., Balakumar, K., dan Franklin, G., 2016, Quillaja saponin: A Prospective Emulsifier for the Preparation of Solid Lipid Nanoparticles, Colloids and Surfaces B: Biointerfaces, Vol. 147 (2016), doi: http://dx.doi.org/10.1016/j.colsurfb.2 016.07.065.

Sivadasan, D., Madavan, B., Penmatsa, S.D., dan Bathini, S.T., 2013, Formulation and Characterization of Solid Lipid Nanoparticles of Rifampicin, Erciyes Medical Journal, Vol. 35(1), doi: 10.5152/etd.2013.01.

Sriarumtias, F.F., Darijanto, S.T., dan Damayanti, S., 2017, Formulasi dan Uji Potensi Antioksidan Nanostructured Lipid Carrier (NLC) Retinil Palmitat, Acta Pharmaceutica Indonesia, Vol. 42(1).

Suprapto, S., 2019, Formulasi Napolion (Nanopartikel Lotion) Antiinflamasi Kombinasi Ekstrak Daun Gelenggang Dan Sirih Merah, Jurnal Farmasi (Journal of Pharmacy), Vol. 1(1), ISSN: 2656-890.

Suprobo, G., dan Rahmi, D., 2015, Pengaruh Kecepatan Homegenisasi terhadap Sifat Fisika dan Kimia Krim Nanopartikel 
dengan Metode High Speed Homogenization (HSH), Jurnal Litbang Industri, Vol. 5(1), ISSN: 2502-5007.

Thakkar, A., Chenreddy, S., Wang, J., dan Prabhu, S., 2015, Evaluation of Ibuprofen Loaded Solid Lipid Nanoparticles and Its Combination Regimens for Pancreatic Cancer Chemoprevention. International Journal of Oncology, Vol. 46(4), doi: 10.3892/ijo.2015.2879.

Weber, S., Zimmer, A., dan Pardeike, J., 2014, Solid lipid Nanoparticles (SLN) and Nanostructured Lipid Carriers (NLC) for Pulmonary Application: A Review of the State of the Art, European Journal of Pharmaceutics and Biopharmaceutics, Vol. 86(1), doi: http://dx.doi.org/10.1016/j.ejpb.2013. 08.013.

Woo, J.O., Misran, M., Lee, P.F., dan Tan, L.P., 2014, Development of a Controlled Release of Salicylic Acid Loaded Stearic Acid-Oleic Acid Nanoparticles in Cream for Topical Delivery, The Scientific World Journal, Vol. 2014, doi:

http://dx.doi.org/10.1155/2014/20570 3.

Xie, S., Zhu, L., Dong, Z., Wang, X., Wang, Y., Li, X., dan Zhou, W., 2011, Preparation, Characterization and Pharmacokinetics of Enrofloxacin-loaded Solid Lipid Nanoparticles: Influences of Fatty Acids, Colloids and Surfaces B: Biointerfaces, Vol. 83(2), doi: 10.1016/j.colsurfb.2010.12.014.

Yadav, N., Khatak, S., dan Sara, U.S., 2013, Solid Lipid Nanoparticles-a Review, International Journal of Applied Pharmaceutics, Vol.5(2), ISSN- 09757058.

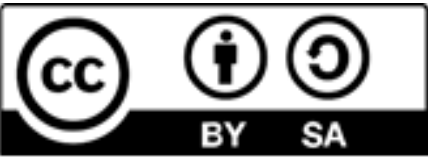

